\title{
Genetic variability in different growth forms of Dendrocalamus strictus: Deogun revisited
}

\author{
Solomon Das ${ }^{1^{*}}\left(\mathbb{D}\right.$, Y. P. Singh ${ }^{2}$, Yogesh K. Negi ${ }^{3}$ and P. C. Shrivastav ${ }^{4}$
}

\begin{abstract}
Background: Bamboo is among the important plants that help shape the socio-economic fabric of rural India. It provides employment, sustains business ventures, has medicinal applications and even helps in carbon sequestration. Out of 125 indigenous species, Dendrocalamus strictus (Roxb.) Nees occupies 53\% of the area of bamboo in the country. Moreover, D. strictus may be used in afforestation of wastelands and rural development programmes due to its adaptability in wider landscapes. Dendrocalamus strictus has different growth forms based on edaphic factors and climatic conditions. DNA profiling was used to analyse the genetic diversity among the different growth forms of $D$. strictus present in three different locations of Uttarakhand.

Methods: The study area includes three locations, first, reserve forest of the Forest Research Institute (FRI), Dehradun; second, Shivpuri near Byasi, Rishikesh; and third, Chiriapur range (Haridwar district). A standard method was used to isolate DNA from young leaves from ten clumps of each growth form. Ten RAPD primers were screened for polymorphism from $A$ and $N$ operon primers and a standard PCR protocol was followed to amplify and visualise DNA bands. The data matrix was analysed and interpreted using statistical software and methods.

Results: The cluster analysis, genetic structure parameters, moderate coefficient of gene differentiation and low gene flow value all indicated that these growth forms are genetically dissimilar and that geographic separation as well as physiological/flowering barriers has influenced these variations. These genetically different growth forms can be called ecotypes.
\end{abstract}

Conclusions: Such a study has not been attempted previously with bamboo and will help inform the conservation of the genetic pool of bamboo ecotypes. Seeds of these ecotypes are monocarpic in nature, which means that bamboo plants flower once in their lifetime, so they must be collected and multiplied (as plantations) in their respective habitats.

Keywords: Bamboo, Ecotypes, RAPD, Variability

\section{Background}

Bamboos are a type of plant that play a major role in the total forest cover $(21.1 \%)$ of the Indian sub-continent, contributing $12.8 \%$ to the total forest area of the country (Forest Survey of India 2011). India has the second richest genetic pool of bamboo after China (Bystriakova et al. 2003). Bamboo, traditionally known as the "poor man's timber", is considered a potential export item by the Indian Government for an export market valued at 12 Bn Indian Rupees. The potential size of the industry can be over several million US dollars in coming years.

\footnotetext{
* Correspondence: solo77das@gmail.com

'Vimix Solutions Private Limited, Dehradun 248001, India

Full list of author information is available at the end of the article
}

The National Mission on Bamboo Technology and Trade Development was launched by the Planning Commission of India in 2003, and one of its objectives was to develop several initiatives to place bamboo as a group of key species in the research and development agenda. For example, bamboo plantations can contribute as an important component of the ambitious Greening India Programme (2010-2020; http://www.thehindu.com/news /national/green-india-mission-to-double-afforestation-ef forts-by-2020/article438506.ece).

There are 125 indigenous and 11 exotic species of bamboos belonging to 23 genera in India (Varmah \& Bahadur 1980; Tewari 1992), and Dendrocalamus strictus (Roxb.) Nees (common English name equivalent being "male bamboo") is one of the most important species. It accounts for 
$53 \%$ of the total bamboo area in India and is one of the predominant bamboo species in Uttar Pradesh, Madhya Pradesh, Orissa and Western Ghats. Dendrocalamus strictus is widely distributed in India, especially in semi-dry and dry zones along plains and hilly tracts to an elevation of $1000 \mathrm{~m}$, and can tolerate temperatures as low as $-5{ }^{\circ} \mathrm{C}$ and as high as $45^{\circ} \mathrm{C}$. This species is mainly found in drier, open deciduous forests in hill slopes, ravines and alluvial plains. It prefers well-drained, poor, coarse-textured and stony soils. It occurs naturally on sites receiving as low as $750 \mathrm{~mm}$ of rainfall. It is suitable for reclamation of ravine land. It is widely used as a raw material in paper mills, and also for a variety of other purposes such as construction, agricultural implements, musical instruments and furniture. Young shoots are commonly used as food, and decoctions of leaves, nodes and siliceous matter are used in traditional medicines (Muthukumar \& Udaiyan 2006).

Deogun (1937) differentiated three major growth forms of $D$. strictus on the basis of edaphic conditions, isolation aspect, temperature and humidity. These forms grow in different geographical locations and exhibit variation in appearance, and in arrangement and crosssectional thicknesses of culms. They are termed "common", "large" and "dwarf" types. The common type is further categorised as:
- Culms with relatively thin walls usually occur in moist shady depressions.

- Culms that are more or less solid usually occur in hot exposed ridges.

- Culms with moderately thick walls are usually found under normal conditions of growth.

Rawat (2005) studied these subtypes of the common type of growth form located in three different locations (Dehradun, Shivpuri and Chiriapur) of Uttarakhand State, India. That study reported that D. strictus located at the Forest Research Institute (FRI) campus at Dehradun (a valley) had open upright and tall clumps (approx. range 3-6 m) with hollow culms. Those at Shivpuri (lower Himalayas) had moderately tall clumps (approx. range $2-4 \mathrm{~m}$ ) that were partially closed and intertwined with a mixture of solid and hollow culms, while clumps of bamboos in the Chiriapur locality (close to River Ganges) were shorter, bushy, closed and highly intertwined with solid culms (approx. range 1.1-1.5 m).

To confirm the genetic variability in and among these growth forms, Randomly Amplified Polymorphic DNA (RAPD), a low-cost, rapid and widely prevalent marker type, was used (Belaj et al. 2001; Deshwall 2005). Several workers have studied the phylogenetic relationships and

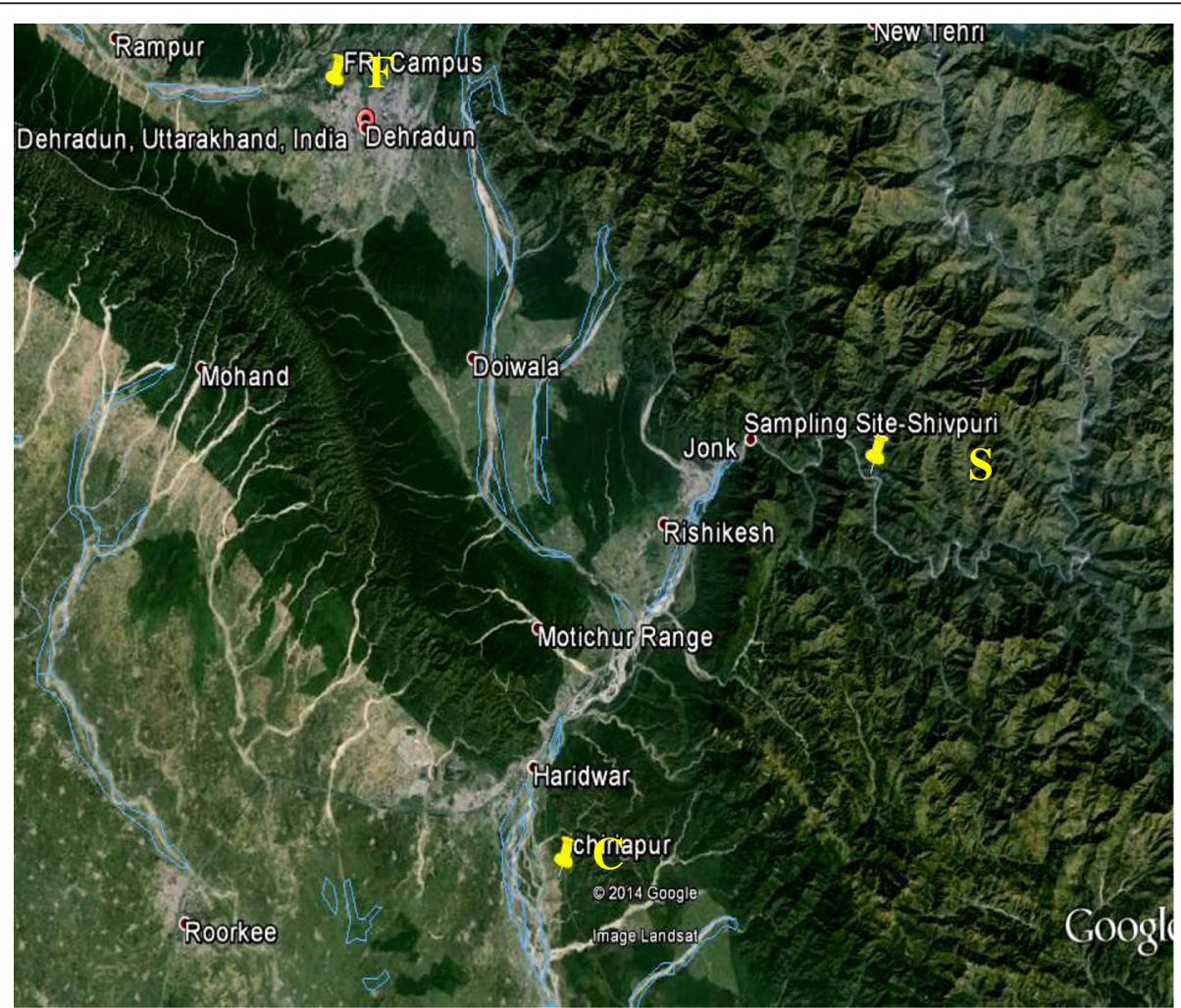

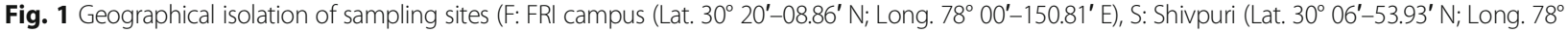
$25^{\prime}-49.72^{\prime} \mathrm{E}$ ) and C: Chiriapur (Lat. $29^{\circ} 52^{\prime}-53.25^{\prime} \mathrm{N}$; Long. $78^{\circ} 11^{\prime}-03.37^{\prime} \mathrm{E}$ ) showing physical barriers such as mountain range as well as rivers and rivulets. (Source: Google Earth) 
characterisation of bamboo (Nayak 2003; Das et al. 2005; Bhattacharya et al. 2006; Bhattacharya et al. 2009). Up till now, no study has reported the nature of genetic differentiation of these growth forms and the role of local edaphic and climatic factors specifically in the case of D. strictus.

\section{Methods}

\section{Sampling locations}

The study involved material from three locations (Fig. 1): first, reserve forest of the FRI, Dehradun(F); second, Shivpuri near Byasi (Rishikesh) (S); and third, Chiriapur range (Haridwar district) (C). These locations were selected based on the exclusive presence of different growth forms of D. strictus (Figs. 2 and 3). Climatic and soil physico-chemical parameters were also recorded (Table 1).

\section{Molecular study}

Young leaves $(100 \mathrm{~g})$ were collected from 10 clumps from each growth form (corresponding to sampling localities). These leaves were preserved at $-80{ }^{\circ} \mathrm{C}$. DNA isolations from each leaf-tissue sample were performed in three replicates. The genomic DNA was extracted from young leaves using the $N$-acetyl- $N, N, N$-trimethylammonium bromide (CTAB) method described by Doyle and Doyle
(1990). Young leaves were used to ensure better DNA yield and quality (Gielis, 1997). After isolation, DNA was quantified and assessed for its purity. A modified RAPD method was used with GenePro (Bioer) thermocycler. Seven RAPD primers were screened for polymorphism using $\mathrm{A}$ and $\mathrm{N}$ operon primer kits (Operon Technologies Inc., Alameda, California, USA) (Nayak et al., 2003). Briefly, each $25 \mu \mathrm{L}$ polymerase chain reaction (PCR) mixture consisted of $20 \mathrm{ng}$ genomic DNA, $100 \mathrm{mM}$ of each dNTP, $100 \mathrm{pM}$ of each primer (Table 2), $25 \mathrm{mM}$ of $\mathrm{MgCl}_{2}, 5 \mathrm{U} / \mu \mathrm{L}$ of $\mathrm{Taq}$ polymerase and PCR buffer $(10 \times)$. All the reagents, like buffers and loading dye, used in RAPD were prepared by the standard method of Nayak et al. (2003).

PCR tubes containing reaction mixture were placed in the block of PCR (GenePro-Bioer) and programmed for initial denaturation at $94{ }^{\circ} \mathrm{C}$ for $4 \mathrm{~min}$ followed by denaturation $\left(94{ }^{\circ} \mathrm{C} ; 1 \mathrm{~min}\right)$, annealing $\left(37^{\circ} \mathrm{C} ; 1 \mathrm{~min}\right)$ and extension $\left(72{ }^{\circ} \mathrm{C} ; 2 \mathrm{~min}\right)$ for 45 cycles. The final extension was performed at $72{ }^{\circ} \mathrm{C}$ for $10 \mathrm{~min}$. Amplified DNA fragments were then separated on $1.8 \%$ agarose gel stained with ethidium bromide and the gel photographed under UV light using a gel doc system (UVP). The molecular sizes of the amplification products were estimated using a $100 \mathrm{bp}$ DNA ladder (100-3000 bp; qARTA Bio, Inc.).

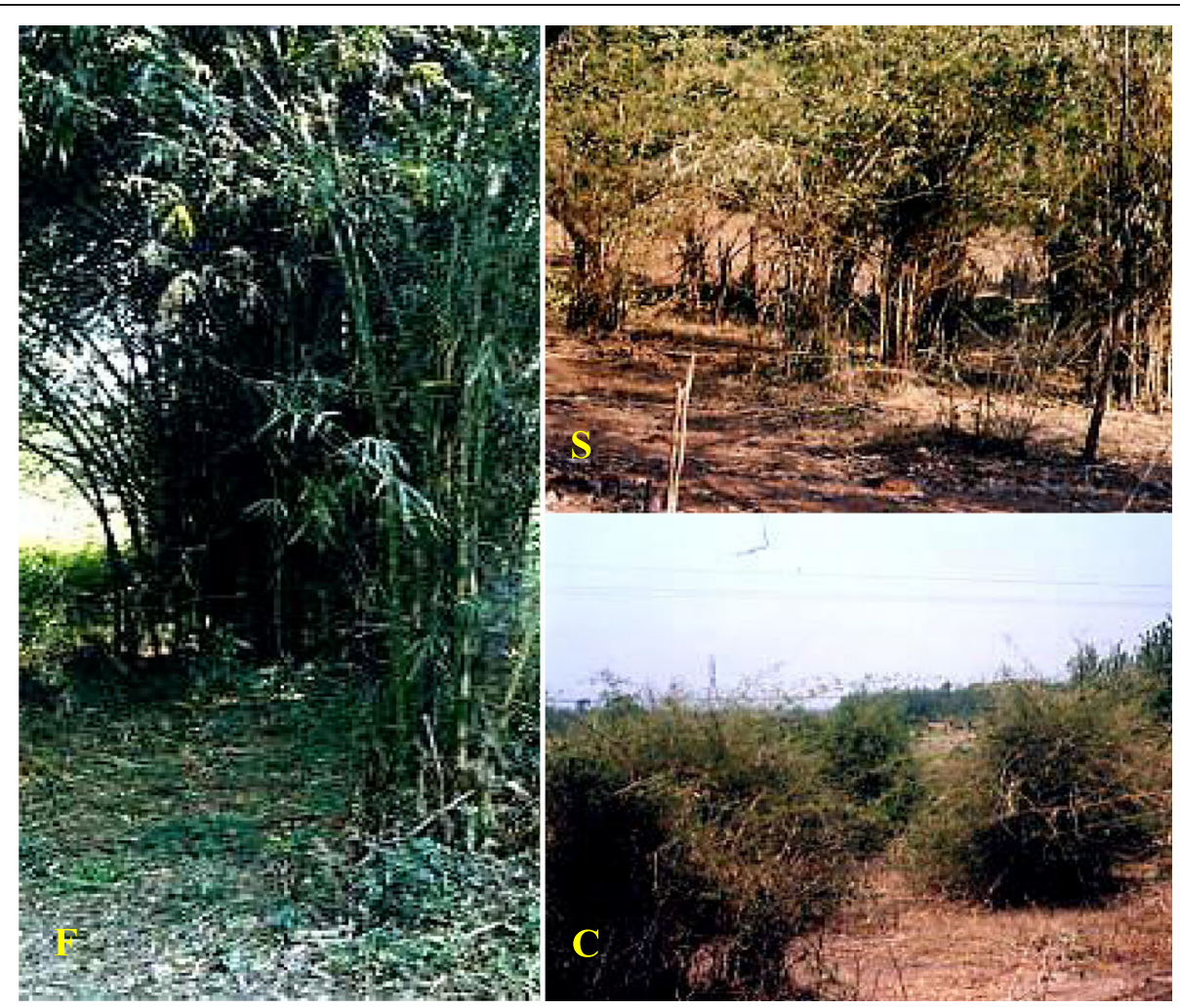

Fig. 2 General views of Dendrocalamus strictus growth forms at different locations in Uttarakhand. Dendrocalamus strictus at FRI campus (F), near Byasi in Shivpuri range (S) and Chiriapur range (C). Source: Rawat, 2005 


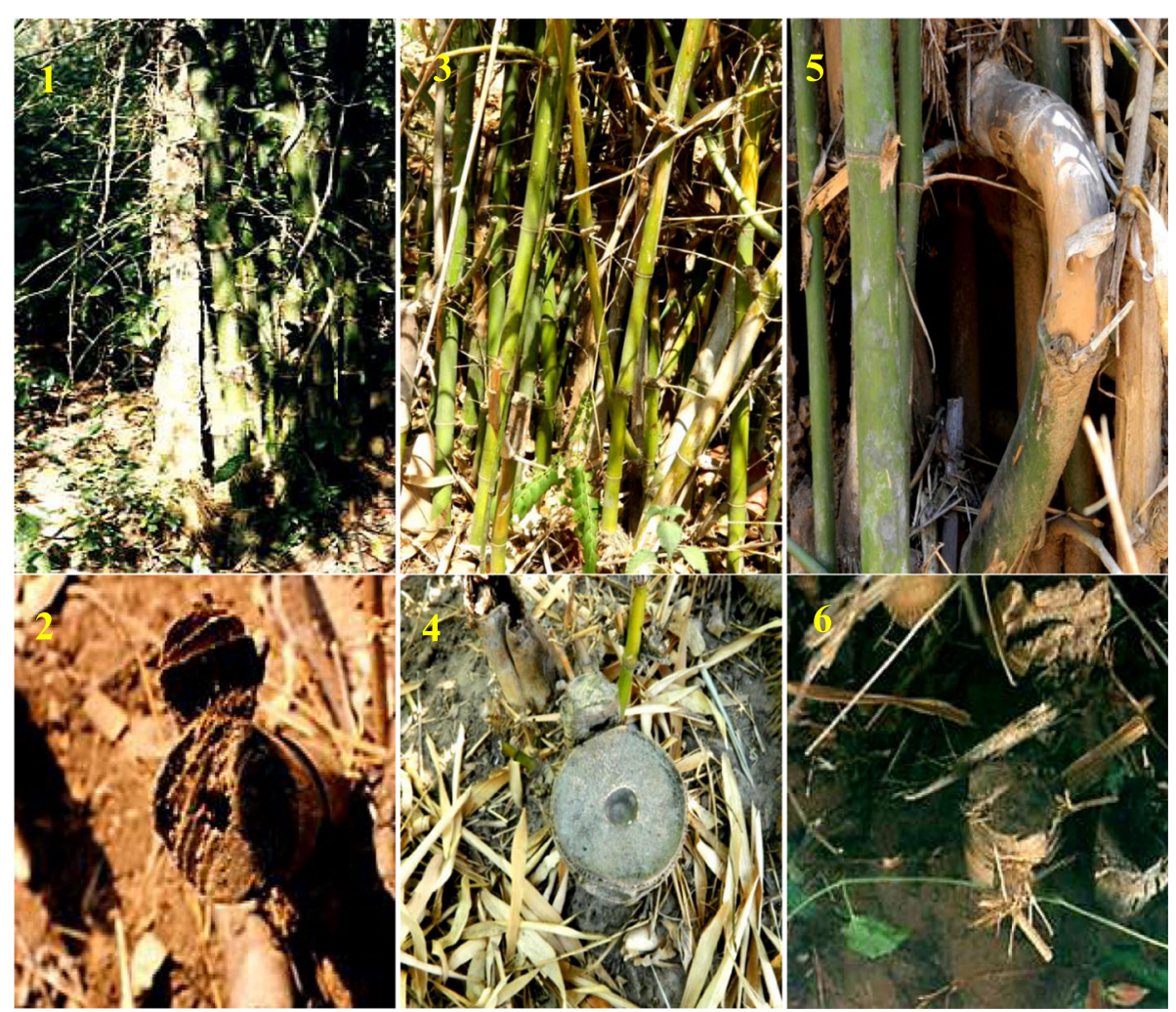

Fig. 3 Clump nature and internal culm structure of Dendrocalamus strictus growth forms growing at different locations in Uttarakhand. Open, straight bamboo clump $(1,2)$ and hollow bamboo culm at FRI campus (Site-F), partially closed, intertwined clump $(3,4)$ and partially hollow culm at Byasi, Shivpuri range (Site-S) and closed, highly intertwined clump (5,6) and solid clump at Chiriapur range (Site-C). Source: Rawat, 2005

Table 1 Climatic conditions and physico-chemical properties of soils of different locations

\begin{tabular}{llll}
\hline Parameter & $\begin{array}{l}\text { FRI campus } \\
(\mathrm{F})\end{array}$ & $\begin{array}{l}\text { Shivpuri } \\
(\mathrm{S})\end{array}$ & $\begin{array}{l}\text { Chiriapur } \\
(\mathrm{C})\end{array}$ \\
\hline Annual rainfall (mm) & 2060.0 & 1706.8 & 1261.5 \\
Min. \& max. temperature $\left({ }^{\circ} \mathrm{C}\right)$ & $3.9-33.2$ & $0.2-32.1$ & $7.5-36.9$ \\
Elevation above sea level $(\mathrm{m})$ & 435 & 372 & 314 \\
Clay (\%) & 13.4 & 16.2 & 10.6 \\
Silt (\%) & 15.4 & 16.1 & 10.4 \\
Sand (\%) & 71.2 & 67.7 & 79.0 \\
Textural class & Loam & Loam & Sandy loam \\
$\quad$ Soil reaction (pH) & 6.8 & 6.6 & 6.2 \\
$\quad$ Electrical conductivity $\left(\mathrm{dsm}{ }^{-1}\right.$ ) & 0.24 & 0.25 & 0.18 \\
Organic carbon (\%) & 2.4 & 2.0 & 1.0 \\
Nitrogen (kg/ha) & 375.0 & 204.0 & 168.0 \\
Available P (kg/ha) & 69.9 & 53.8 & 12.5 \\
Available K (kg/ha) & 645.1 & 329.3 & 309.1 \\
\hline
\end{tabular}

\section{Data analysis}

Each polymorphic band was considered as a binary character and was scored 0 (absent) or 1 (present) for each sample and assembled in a data matrix. Only intensely stained, unambiguous and reproducible bands were scored for analysis. Similarity index was estimated using the Dice coefficient of similarity (Nei \& Li 1979). Cluster analysis was carried out on similarity estimates by the unweighted pair-group method with arithmetic average (UPGMA), using NTSYS-PC, version 1.8 (Rohlf, 1998). Percentages of polymorphic bands (PPB) were calculated for each primer. The software program POPGENE v. 1.31 (Yeh et al. 1999) was used to obtain statistics for the genetic diversity parameters, percentage of polymorphic loci $(P)$, allele number per locus $(A)$, effective allele number per locus $\left(\hat{A}_{\mathrm{e}}\right)$ and expected heterozygosity $\left(\hat{H}_{\mathrm{e}}\right)$. Nei's gene diversity $(\hat{h}$; (Nei 1973)), Shannon's diversity index ( $\hat{I}$; (Lewontin 1972)), within-population genetic diversity $\left(\underline{\hat{H}}_{\mathrm{pop}}\right)$, total genetic diversity $\left(\hat{H}_{\mathrm{sp}}\right)$, within-population gene diversity $\left(\underline{\hat{H}}_{\mathrm{S}}\right)$, total gene diversity $\left(\underline{\hat{H}}_{\mathrm{T}}\right)$, genetic differentiation coefficient $\left(\underline{\hat{G}}_{s t}\right)$ and gene flow $\left(\underline{\underline{N}}_{\mathrm{m}}\right)$ were quantified. Nei's (Nei 1973) genetic identity and genetic distance between populations were also calculated. 
Table 2 Primer details used in RAPD analysis of different growth forms/sampling localities of D. strictus

\begin{tabular}{|c|c|c|c|c|c|c|}
\hline $\begin{array}{l}\text { Name of the } \\
\text { primer }\end{array}$ & $\begin{array}{l}\text { Sequence of the } \\
\text { primer }\end{array}$ & $\begin{array}{l}\text { Conc. } \\
\text { (pmol/ } \mu \mathrm{L})\end{array}$ & OD & $\begin{array}{l}\text { Mol. } \\
\text { wt. }\end{array}$ & $\begin{array}{l}\text { GC } \\
(\%)\end{array}$ & $\begin{array}{l}\mathrm{Tm} \\
\left({ }^{\circ} \mathrm{C}\right)\end{array}$ \\
\hline OPA 11 & 5'-CAATCGCCGT-3' & 60.4 & 6.2 & 2988 & 60 & \\
\hline OPA 19 & 5'-CAAACGTCGG-3' & 58.4 & 6.6 & 3037 & 60 & \\
\hline OPA 20 & 5'-GTTGCGATCC-3' & 63.6 & 6.4 & 3019 & 60 & \\
\hline OPN 11 & 5'-TCGCCGCAAA-3' & 56.1 & 6.1 & 2997 & 60 & \\
\hline OPN 13 & 5'-AGCGTCACTC-3' & 61.4 & 6.3 & 2988 & 60 & \\
\hline OPN 20 & 5'-GGTGCTCCGT-3' & 70.2 & 6.8 & 3035 & 70 & \\
\hline OPX 12 & 5'-TCGCCAGCCA-3' & 39.6 & 4.0 & 2972 & 70 & \\
\hline
\end{tabular}

$O D$ optical density, GC guanine-cytosine content, $T m$ melting temperature

\section{Polymorphism information content (PIC)}

The PIC provides an estimate of the discriminating power of a marker. Polymorphic information content was calculated using the following formula (Roldan-Ruiz 2000):

$$
\mathrm{PIC}_{i}=\left[2 f_{i}\left(1-f_{i}\right)\right]
$$

where $\mathrm{PIC}_{i}$ is the polymorphism information content of marker $i, f_{i}$ is the frequency of the marker fragments which were present and $1-f_{i}$ is the frequency of marker fragments which were absent. PIC was averaged over the fragments for each primer combination.

\section{Resolving power (RP)}

$\mathrm{RP}$ of each primer was calculated according to Prevost and Wilkinson (1999).

$$
\mathrm{RP}=\Sigma \mathrm{Ib}
$$

Where, Ib represents fragment informativeness. The Ib can be represented on a $0-1$ scale by the following formula:

$$
\mathrm{Ib}=1-[2 \times|0.5-p|]
$$

where $p$ is the proportion of all the accessions containing the fragment.

\section{Results}

RAPD banding pattern inference

The seven polymorphic RAPD primers provided useful information for the estimation of genetic diversity within and among different growth forms of $D$. strictus (Figs. 4 and 5). These primers generated 858 reproducible bands, of which 768 (89.5\%; Table 3) were polymorphic. These amplified bands ranged from 200 to $3000 \mathrm{bp}$. The percentages of polymorphic bands (PPBs) ranged from $80 \%$ (OPA-11) to 100\% (OPA-19 and 20, OPN-11 and 20 and OPX-12). The number of bands amplified by each primer ranged from 7 (OPA-20 and OPX-12) to 17 (OPN13) with an average of 11.9 bands. The PIC varied from 0.27 (OPA-11 and OPN-20) to 0.37 (OPN-11) with an average of 0.31 . Likewise, the resolving power of the RAPD primers was ranged from 3.5 (OPA-20) to 7.7 (OPN-13) with an average of 5.2.

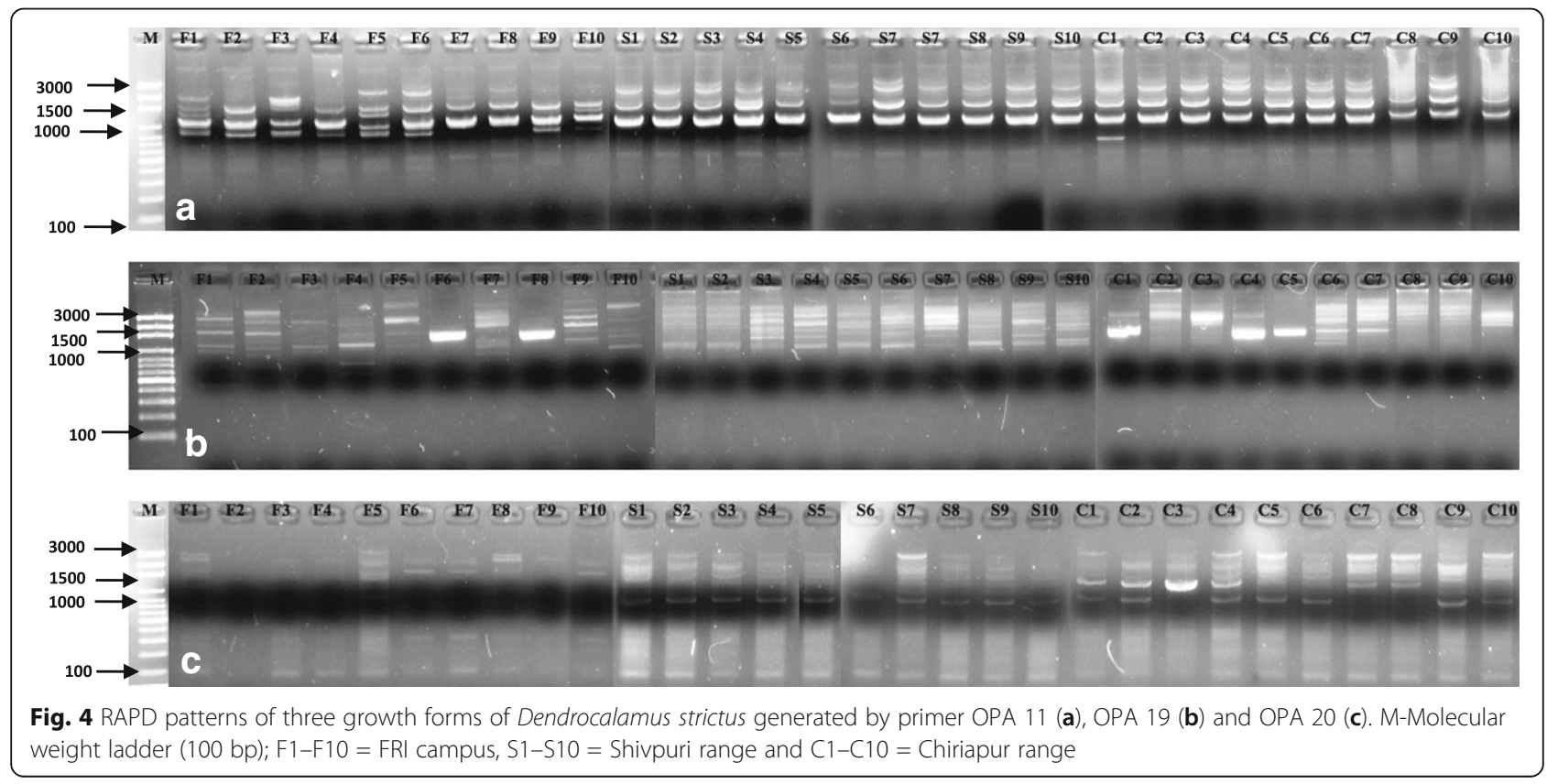




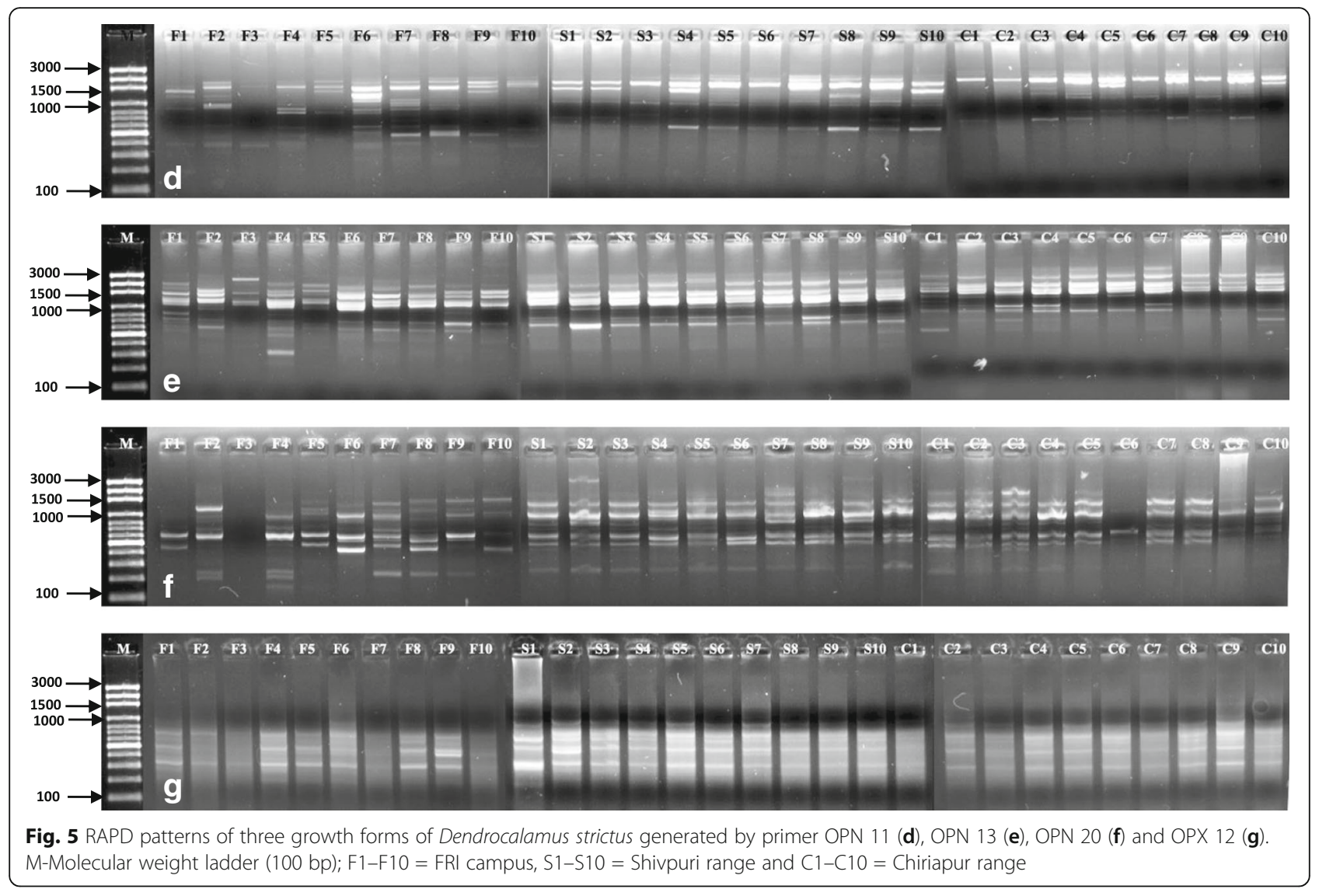

Cluster analysis and genetic structure and differentiation within and among different growth forms/sampling locations of $D$. strictus

A series of UPGMA algorithms was used to generate an average similarity matrix representing Nei and Li's coefficient to cluster 30 members (10 clumps from each growth form) of the different growth forms of D. strictus. The highest similarity coefficient was observed between clumps of Shivpuri S6 and S5 (0.95; Table 4), whereas a minimum value (0.17) was recorded between plants of Chiriapur (C2) and FRI campus (F3). The UPGMA dendrogram of cluster analysis of RAPD markers showing the genetic relatedness among the growth forms ranged from 55 to $93 \%$ approximately (Fig. 6). Clusters were grouped as A and B. Cluster A1 consisted of all the plants of FRI campus barring F3, which stood separately out as cluster C. Cluster B1 consisted of two growth forms of D. strictus (Shivpuri (B1) and Chiriapur (B2)). Clusters

Table 3 PCR details of 30 clumps of the three growth forms/sampling locations of D. strictus

\begin{tabular}{|c|c|c|c|c|c|c|c|c|c|c|}
\hline $\begin{array}{l}\text { Name of } \\
\text { primer }\end{array}$ & $\begin{array}{l}\text { Sequence of } \\
\text { the primer }\end{array}$ & $\begin{array}{l}\text { GC } \\
(\%)\end{array}$ & $\begin{array}{l}\text { Total number of } \\
\text { amplified bands }\end{array}$ & $\begin{array}{l}\text { No. of } \\
\text { monomorphic } \\
\text { bands }\end{array}$ & $\begin{array}{l}\text { No. of } \\
\text { polymorphic } \\
\text { bands }\end{array}$ & $\begin{array}{l}\text { Percent of } \\
\text { polymorphic } \\
\text { bands }\end{array}$ & $\begin{array}{l}\text { Total no. } \\
\text { of loci }\end{array}$ & $\begin{array}{l}\text { Size } \\
\text { range } \\
(\mathrm{kb})\end{array}$ & $\mathrm{PIC}$ & $\begin{array}{l}\text { Resolving } \\
\text { Power }\end{array}$ \\
\hline OPA 11 & 5'-CAATCGCCGT-3' & 60 & 121 & 2 & 8 & 80.0 & 10 & $0.8-3.0$ & 0.27 & 3.8 \\
\hline OPA 19 & 5'-CAAACGTCGG-3' & 60 & 81 & 0 & 13 & 100 & 13 & $0.7-3.0$ & 0.28 & 5.4 \\
\hline OPA 20 & 5'-GTTGCGATCC-3' & 60 & 68 & 0 & 7 & 100 & 7 & $0.8-3.0$ & 0.33 & 3.5 \\
\hline OPN 11 & 5'-TCGCCGCAAA-3' & 60 & 134 & 0 & 15 & 100 & 15 & $0.4-2.0$ & 0.37 & 7.5 \\
\hline OPN 13 & 5'-AGCGTCACTC-3' & 60 & 193 & 2 & 15 & 88.2 & 17 & $0.2-3.0$ & 0.30 & 7.7 \\
\hline OPN 20 & 5'-GGTGCTCCGT-3' & 70 & 151 & 0 & 14 & 100 & 14 & $0.2-3.0$ & 0.27 & 5.1 \\
\hline OPX 12 & 5'-TCGCCAGCCA-3' & 60 & 110 & 0 & 7 & 100 & 7 & $0.2-1.0$ & 0.34 & 3.6 \\
\hline Total & & 430 & 858 & 4 & 79 & 668.2 & 83 & - & 2.2 & 36.6 \\
\hline Mean & & 61.4 & 122.6 & 0.6 & 11.3 & 95.5 & 11.9 & $0.5-2.6$ & 0.31 & 5.2 \\
\hline
\end{tabular}

GC guanine-cytosine content, PIC polymorphism information content 


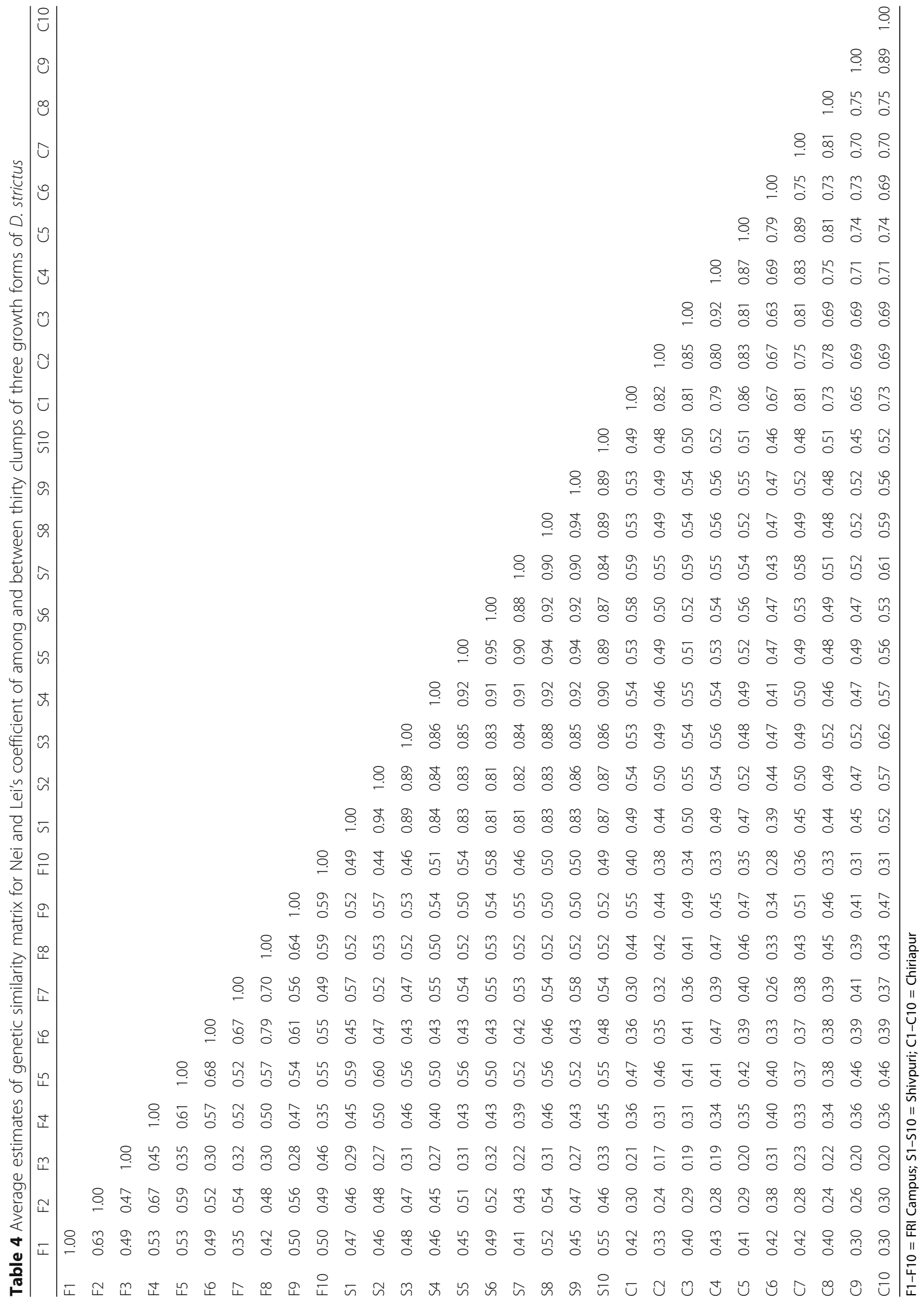




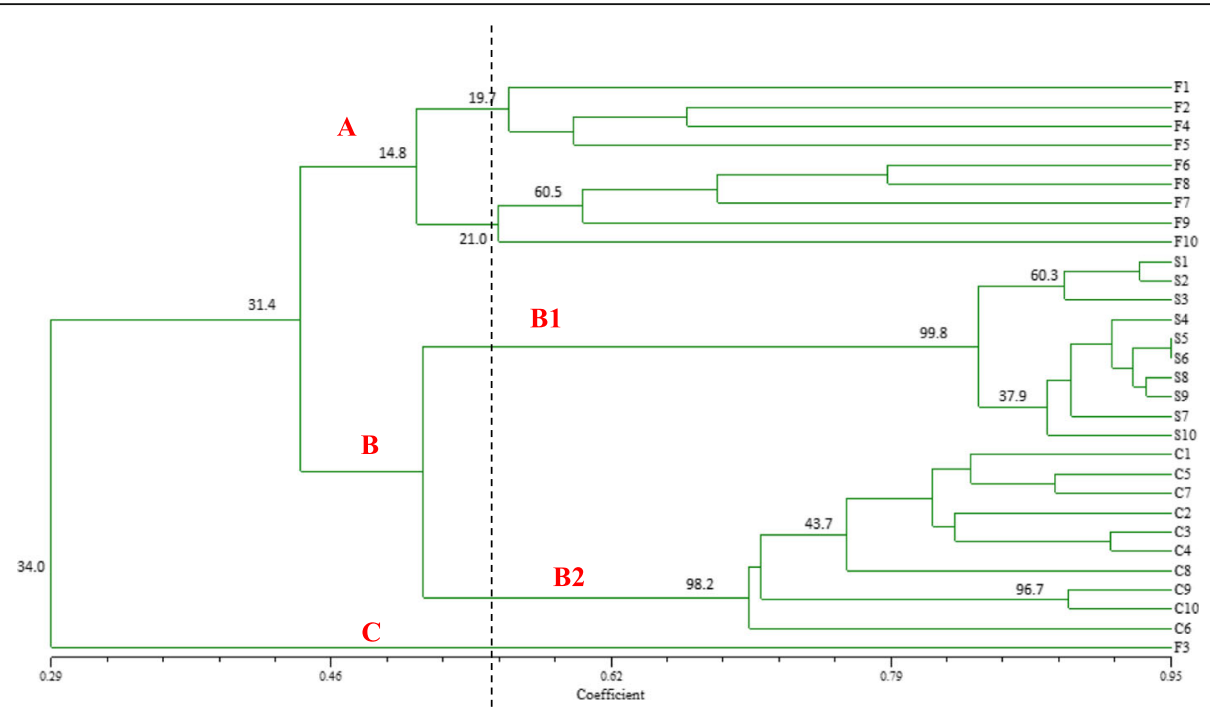

Fig. 6 UPGMA dendrogram of cluster analysis of RAPD markers showing the genetic relatedness among the growth forms of Dendrocalamus strictus. Fork number indicates the percentage of times the cluster occurred in a bootstrap analysis. F1-F10 = FRI campus, S1-S10 = Shivpuri range and $\mathrm{C} 1-\mathrm{C} 10=$ Chiriapur range

B1 and B2 had high bootstrap values (99.8 for Shivpuri and 98.2 for Chiriapur). The principal coordinate analysis (PCoA) (Fig. 7) revealed the presence of three distinct groups, with the most highly diverse group at the FRI campus and the least diverse at Shivpuri ( $\mathrm{C} 3$ axis). The principal coordinate plots (Fig. 8) show that the three separate groups are in agreement with the three different growth forms belonging to three geographic locations.

The estimated mean number of observed alleles $\left(\underline{\underline{N}}_{\mathrm{a}}\right)$ was highest in bamboos at the FRI campus (1.699; Table 5) and lowest in members of Shivpuri (1.325).

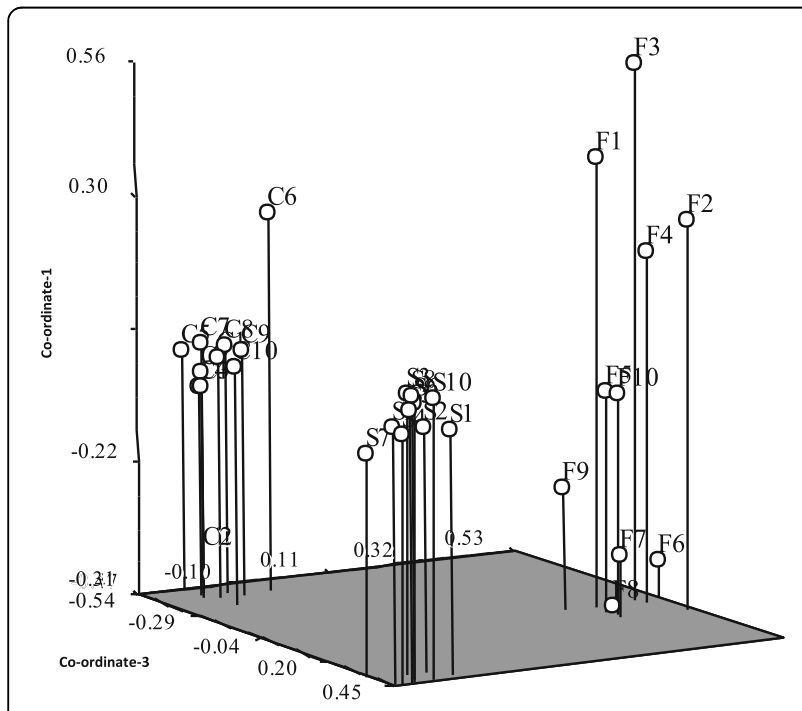

Fig. 7 Three-dimensional representation using PCoA for genetic relatedness among the growth forms of Dendrocalamus strictus
Likewise, the most effective alleles $\left(\underline{\underline{N}}_{\mathrm{e}}\right)$ were observed in FRI campus (1.288) and the least in Shivpuri (1.124). When all the population samples were considered, the overall mean of $\underline{\tilde{N}}_{\text {e }}$ was 1.430 . The expected Nei's genetic diversity $(\underline{\hat{\boldsymbol{h}}})$ and Shannon's diversity index $(\underline{\hat{\boldsymbol{I}}})$ were recorded to be higher within members of FRI campus $(\hat{\boldsymbol{h}}=0.19, \hat{\underline{I}}=0.30)$ and lower within Shivpuri culms $(\underline{\hat{\boldsymbol{h}}}=0.08, \overline{\hat{I}}=0.12)$. Assuming the Hardy-Weinberg equilibrium, the average expected diversity overall $\left(\underline{\hat{H}}_{t}\right)$ was found to be 0.26 , with $\hat{H}_{s}$ of 0.13 among the members of a population (Table 5 ). Observed Shannon indices were 0.40 overall $\left(\underline{\hat{H}}_{s p}\right)$ and 0.23 (among individuals of a population), while the observed $\hat{G}_{s t}$ among different growth forms of $D$. strictus was moderate to high (0.49; Table 6); likewise, estimated gene flow $\left(\underline{\underline{N}}_{m}\right)$ among populations of different growth forms was 0.51. In UPGMA dendrograms (Fig. 9), based on Nei's genetic distance, the growth forms of FRI campus and Chiriapur were in one group, while Shivpuri behaved as a separate group. The observed genetic distance was least between Chiriapur and FRI campus (0.215; Table 7) and greatest between Chiriapur and Shivpuri (0.305).

\section{Discussion}

\section{RAPD banding pattern}

Deogun (1937) differentiated different growth forms of D. strictus in and around Dehradun that were based on various parameters including geographical isolation aspects (different locations), edaphic and climatic (temperature and humidity) conditions. We found that these morphological variants or growth forms could be resolved genetically using RAPD markers. For example, 


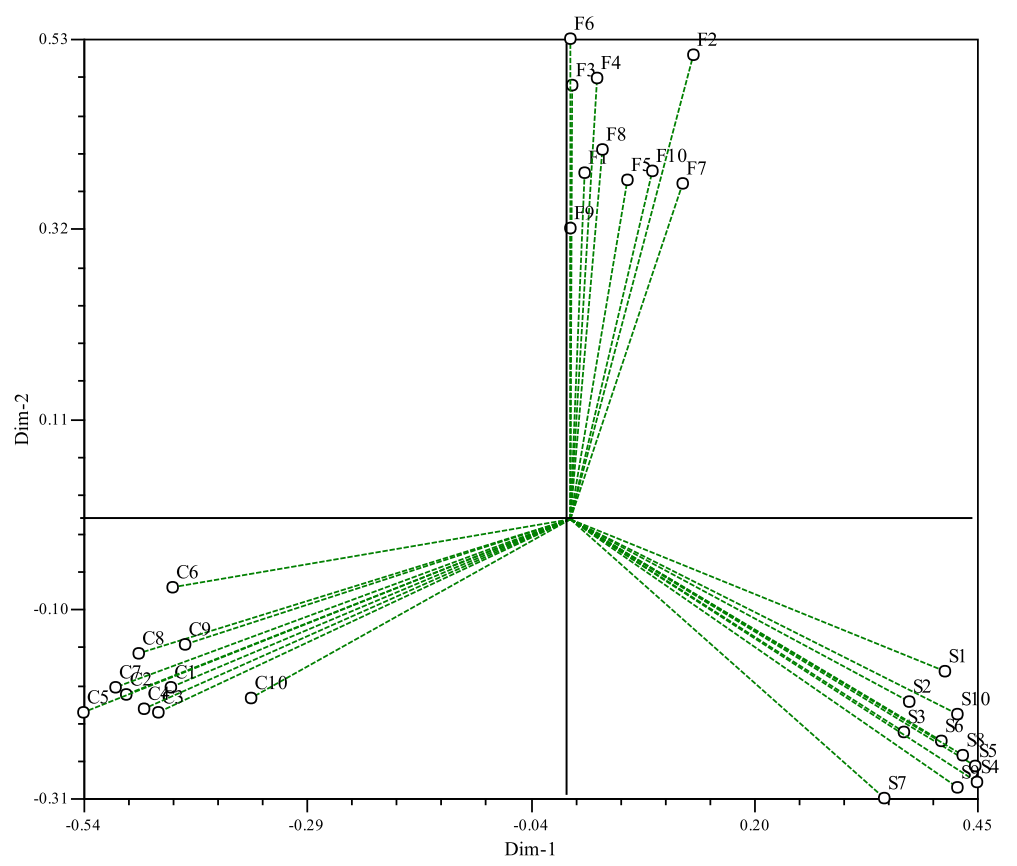

Fig. 8 Distribution of 30 culms of three different growth forms of Dendrocalamus strictus by 2-dimensional principal coordinate analysis. PCo axis 1 and PCo axis 2 account for 21.9 and 15.9\% of the variations, respectively

high polymorphism, to the tune of $95.2 \%$ (Table 3), allowed grouping of growth forms into distinct clusters (Fig. 6). Likewise resolution into three distinct populations by PCoA (Figs. 7 and 8), and the observed gene differentiation coefficient (0.49) and gene flow statistic (0.51), highlighted some chances of genetic exchange. This could be attributed to the fact that the bamboos are wind-pollinated and they have physical/physiological barriers that prevent self-pollination and favour crosspollination (Venkatesh 1984; Nadgauda et al. 1993; John et al. 1994, 1995). However, present physical and geographical separation among these growth forms could have promoted inbreeding over outcrossing (Table 1 ). No precedent could be traced in the literature with regard to growth forms of bamboos, in general, and D. strictus in particular.

Table 5 Genetic variability statistics for the members of the three growth forms of D. strictus

\begin{tabular}{llllll}
\hline $\begin{array}{l}\text { Growth } \\
\text { form/ } \\
\begin{array}{l}\text { sampling } \\
\text { locality }\end{array}\end{array}$ & $\begin{array}{l}\text { Percent } \\
\text { polymonds }\end{array}$ & $\begin{array}{l}\text { Mean } \\
\text { bumber } \\
\text { of observed } \\
\text { alleles }\left(\underline{\underline{N}}_{a}\right)\end{array}$ & $\begin{array}{l}\text { Mean } \\
\text { number } \\
\text { of effective } \\
\text { alleles }\left(\underline{\underline{N}}_{e}\right)\end{array}$ & $\begin{array}{l}\text { Nei's } \\
\text { genetic } \\
\text { diversity } \\
(\underline{\hat{h}})\end{array}$ & $\begin{array}{l}\text { Shannon } \\
\text { diversity } \\
\text { index }(\hat{\underline{n}})\end{array}$ \\
\hline $\begin{array}{l}\text { FRI } \\
\text { Campus }\end{array}$ & 69.9 & $1.70 \pm 0.4$ & $1.29 \pm 0.3$ & $0.19 \pm 0.2$ & $0.30 \pm 0.2$ \\
$\begin{array}{l}\text { Shivpuri } \\
\text { Chiriapur }\end{array}$ & 32.5 & $1.32 \pm 0.5$ & $1.12 \pm 0.3$ & $0.08 \pm 0.1$ & $0.13 \pm 0.2$ \\
Mean & 49.4 & $1.46 \pm 0.5$ & $1.22 \pm 0.3$ & $0.13 \pm 0.2$ & $0.21 \pm 0.3$ \\
\hline
\end{tabular}

Nayak et al. (2003) used 10 primers (A \& N operon series) to evaluate genetic variability within 12 different species of bamboos including D. strictus. In the present study, only seven out of 10 RAPD primers of the A and $\mathrm{N}$ series were chosen (Table 3). All of the tested primers showed high polymorphism (95.2\%). The high sensitivity of these primers indicates that they may be used to resolve the genetic variability in future studies on $D$. strictus. Out of these seven markers, the PIC value (0.30 and above) and resolving power of OPA-20, OPN-11, 13 and OPX-12 could together be used in screening the diversity of $D$. strictus.

\section{Cluster analysis and genetic structure and differentiation within and among different growth forms/sampling localities of $D$. strictus}

The cluster analysis and PCoA showed high genetic diversity within the plants of FRI campus (Figs. 7 and 8). This high diversity within members of the FRI campus growth forms needs further study by exploring their sources of parental lineage. The F3 plant standing out as outlier requires a molecular approach to confirm its identity, in terms of genetic diversity. Moreover, plants of Shivpuri showed least genetic diversity, which could not be explained in the absence of certain concrete information on the source plant material. The average expected Nei's genetic diversity index (0.132) and Shannon diversity index (0.209) observed for D. strictus were less than observed for D. membranaceus (0.164, 0.249 
Table 6 Overall genetic variability statistics, assuming Hardy-Weinberg equilibrium for the different growth forms of D. strictus

\begin{tabular}{|c|c|c|c|c|c|c|c|c|c|c|}
\hline \multirow[t]{2}{*}{ Parameter } & \multirow[b]{2}{*}{$\begin{array}{l}\text { Mean } \\
\text { number } \\
\text { of } \\
\text { observed } \\
\text { alleles } \\
\left(\underline{N}_{a}\right)\end{array}$} & \multirow[b]{2}{*}{$\begin{array}{l}\text { Mean } \\
\text { number } \\
\text { of } \\
\text { effective } \\
\text { alleles } \\
\left(\underline{N}_{\text {e }}\right)\end{array}$} & \multicolumn{4}{|c|}{ Nei's index } & \multicolumn{3}{|c|}{ Shannon's index } & \multirow{2}{*}{$\begin{array}{l}\text { Percent } \\
\text { polymorphic } \\
\text { bands }\end{array}$} \\
\hline & & & $\overline{\hat{H}}_{t}$ & $\hat{\hat{H}}_{s}$ & $\hat{G}_{s t}$ & $\check{N}_{m}$ & $\hat{\hat{\theta}}_{p o p}$ & $\hat{\hat{H}}_{s p}$ & $\underline{\hat{H}}_{p o p} / \hat{H}_{s p}$ & \\
\hline Mean & 1.952 & 1.430 & 0.261 & 0.133 & 0.493 & 0.514 & 0.209 & 0.403 & 1.928 & 95.2 \\
\hline SD & 0.216 & 0.348 & 0.029 & 0.009 & - & - & 0.236 & 0.225 & - & \\
\hline
\end{tabular}

$\hat{\hat{H}}_{t}$ total gene diversity, $\underline{\hat{H}}_{s}$ gene diversity of within population, $\hat{G}_{s t}$ coefficient of gene differentiation, $\underline{\underline{N}}_{m}$ gene flow index, $\hat{\hat{H}}_{p o p}$ within-population gene diversity, $\underline{\hat{H}}_{s p}$ total gene diversity, $\underline{\hat{H}}_{p o p} / \hat{H}_{s p}$ ratio of genetic diversity within population

(Yang, 2012)). Both these species belong to the hexaploid group. The polyploid taxa tend to show high genetic diversity based on heterozygosity and number of bands amplified. However, why Nei's genetic diversity index and Shannon diversity index are low in D. strictus in comparison to another $6 \mathrm{n}$ species like D. membranaceus needs further exploration and explanation. Further, high genetic diversity was recorded among the three different growth forms of D. strictus $\left(\underline{H}_{t}=0.261 ; \underline{\hat{H}}_{\mathrm{pop}}=0.403\right.$; Table 6) as compared to mean gene diversity among monocotyledons for Nei's expected heterozygosity value (0.144; Hamrick \& Godt 1990). However, Nei’s total genetic diversity and Shannon diversity values of our study material of $D$. strictus were comparable with those of $D$. membranaceus $\left(\underline{\hat{H}}_{t}=0.219 \& \underline{\hat{H}}_{\mathrm{pop}}=0.349\right.$ (Yang, 2012)). Differences among populations can also arise systematically, especially if the environments in various locations expose individuals to different optima for survival and reproduction (fitness). For these and other reasons, populations often diverge from one another in their genetic composition. Such divergence is especially strong and rapid when there is little gene flow between populations (e.g. limited dispersal of seeds or pollen, or limited movement of animals across physiographic barriers) ( ${ }^{1}$ Khashti, D, unpublished report). This was evident in the present study where the seeds of bamboo are not able to disperse freely due to physical barriers among the three populations, and the local environments presumably helped in shaping their genetic makeup.

Likewise, each growth form must have adapted to its local climatic and edaphic conditions and developed into a genomically distinguishable form of $D$. strictus. For example, nutrient-leached sandy loamy soil and low available phosphorus (P) in Chiriapur, close to the River Ganges, may have played a role in shaping the morphological features of the bamboo clumps and culms found there. Anderson et al. (2007) reported that rainfall and soil $\mathrm{P}$ act more like modulating factors in shaping the diversity and composition of tropical grasslands. Chaplin et al. (1993) also reported that there is interdependence among available soil resources, climate, functional groups of plants and physiognomic types (set of functional and morphological attributes) in shaping the parent plant material. Based on these, it may be inferred that a wide range of rainfall, available soil $\mathrm{P}$, and organic matter played a major role in shaping the morphology of these growth forms; for example, clumps at Chiriapur, which were highly intertwined and closed with solid culms, are consistent with low rainfall and low soil nutrients, especially low $\mathrm{P}$, whereas clumps at the FRI campus were more open, straight and taller with hollow culms, which may be in response to high rainfall and organic matter conditions. Hence, these growth forms or genotypes are locally adapted to their environment and can be referred as ecotypes (Hufford \& Mazer 2003). Such ecotype differentiation may be due to the long-term selection pressure that caused these populations to adapt to local environmental and edaphic conditions (Kawecki \& Ebert 2004; Savolainen et al. 2007). Such development of ecotypes due to the adaptational pressures of local climate and soil is also reported in other species such as Pinus taeda L. (Bongarten \& Teskey 1986), Picea abies L. (Oleksyn 1998), Pinus sylvestris L. (Palmroth 1999), Fagus sylvatica L. (MüllerStark 1997; Peuke 2002) and Quercus coccifera L. (Baquedano 2008). Soolanayakanahally et al. (2009) found that species growing in wide geographical ranges showed great potential to acquire larger intraspecific variation in physiology, phenology, morphology and growth rate, which are clearly visible in case of these
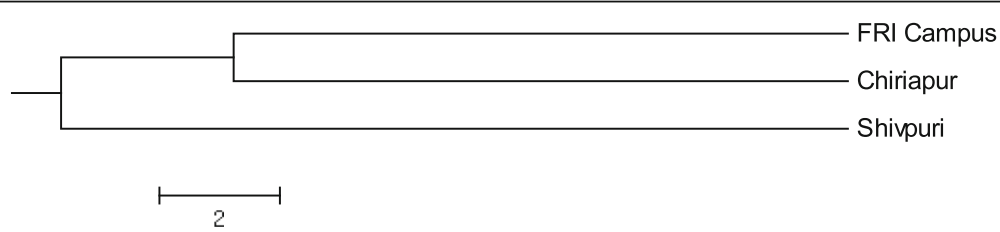

Fig. 9 Dendrogram based Nei's genetic distance among three growth forms of Dendrocalamus strictus 
Table 7 Nei's original measures of genetic identity (above diagonal) and genetic distance (below diagonal)

\begin{tabular}{llll}
\hline POP Id & FRI Campus & Shivpuri & Chiriapur \\
\hline FRI Campus & - & 0.792 & 0.807 \\
Shivpuri & 0.233 & - & 0.737 \\
Chiriapur & 0.215 & 0.305 & - \\
\hline
\end{tabular}

growth forms of D. strictus growing in different geographical locations. The study presented here reports for the first time substantial differences among growth forms of $D$. strictus in India, especially in terms of genetic differentiation. The information may be important to capture and conserve the complete diversity of $D$. strictus, which is a widely present and highly used species in India. Moreover, D. strictus, due to its wider adaptability, can be used in afforestration of diverse wastelands and rural development programmes which can be crucial for economic growth.

A shortcoming of this work was that the growth-form populations of $D$. strictus were not compared in a common-garden trial, which could be slow and difficult to conduct. However, this is seen as far from crucial in the light of the observed DNA marker differentiation.

\section{Conclusions}

Different growth forms of D. strictus which are morphologically different and correspond to different geographic localities have proved to be genomically different. Physical barriers, i.e. three different locations separated by rivers and hills, local edaphic and climatic conditions seem to influence the genetic structure of the $D$. strictus meta population. The genetic variability within the members of same growth form showed less diversity. In future, such study needs to be conducted over a wider geographical area to explore the diversity among or within members of $D$. strictus growth forms present in different parts of India.

\section{Endnote}

${ }^{1}$ Mycorrhizal associations of Olea ferruginea populations in Himachal Pradesh, India. Pre-Ph.D report submitted to FRI (Deemed) University, Dehradun (unpublished).

\section{Acknowledgements}

Authors are thankful to the Head of the Molecular Taxonomy Department of Botany Division, and Director of Forest Research Institute, Dehradun, who provide necessary facilities to conduct all the experiments. We are thankful to Mrs. Seema Singh for editing the article.

\section{Authors' contributions}

$\mathrm{SD}$ is responsible for the study, interpretation and analysis of results, who also contributed in the writing of the manuscript. YPS is responsible for interpretation of results and writing of manuscript. YKN is responsible for the correction of manuscript. PCS is responsible for the correction of manuscript. All authors read and approved the final manuscript.
Funding

None.

Ethics approval and consent to participate

Not applicable.

Consent for publication

Not applicable.

\section{Competing interests}

The authors declare that they have no competing interests.

\section{Publisher's Note}

Springer Nature remains neutral with regard to jurisdictional claims in published maps and institutional affiliations.

\section{Author details}

${ }^{1}$ Vimix Solutions Private Limited, Dehradun 248001, India. ${ }^{2}$ Department of Forest Pathology, Forest Research Institute, Dehradun 248006 , India. ${ }^{3}$ College of Forestry, Uttarakhand University of Horticulture and Forestry, Ranichauri 249199, India. ${ }^{4}$ Department of Soil Science, College of Agriculture, G. B. Pant University of Agriculture and Technology, Pantnagar 263145, India.

Received: 17 October 2016 Accepted: 23 October 2017

Published online: 20 November 2017

\section{References}

Anderson, TM, Ritchie, ME, McNaughton, SJ (2007). Rainfall and soil modify plant community response to grazing in Serengeti National Park. Ecology, 88(5), 1191-1201.

Baquedano, FJ, Valladares, F, Castillo, FJ (2008). Phenotypic plasticity blurs ecotypic divergence in the response of Quercus coccifera and Pinus halepensis to water stress. European Journal of Forest Research, 127(6), 495-506.

Belaj, A, Trujilo, I, Rosa, R, Rallo, L, Gimenez, MJ (2001). Polymorphism and discrimination capacity of randomly amplified polymorphic markers in an olive germplasm bank. Journal of the American Society for Horticultural Sciences, 126, 64-71.

Bhattacharya, S, Das, M, Bara, R, Pal, A (2006). Morphological and molecular characterization of Bambusa tulda with a note on flowering. Annals of Botany, 98, 529-535.

Bhattacharya, S, Ghosh, JS, Das, M, Pal, A (2009). Morphological and molecular characterization of Thamnocalamus spathiflorus subsp. spathiflorus at population level. Plant Systematics and Evolution, 282, 13-20.

Bongarten, BC, \& Teskey, RO (1986). Water relations of loblolly pine seedlings from diverse geographic origins. Tree Physiology, 1, 265-276.

Bystriakova, N, Kapo, V, Lysenko, I, Stapleton, C (2003). Distribution and conservation status of forest bamboo biodiversity in the Asia-Pacific region. Biodiversity and Conservation, 12, 1833-1841.

Chaplin III, FS, Rincon, E, Huante, P (1993). Environmental response of plants and ecosystems as predictors of the impact of global change. Journal of Biosciences, 18(4), 515-524.

Das, M, Bhattacharya, S, Pal, A (2005). Generation and characterization of SCARs by cloning and sequencing of RAPD products: a strategy for species-specific marker development in bamboo. Annals of Botany, 95, 835-841.

Deogun, PN (1937). The silviculture and management of the bamboo Dendrocalamus strictus Nees. New Forest, 2(4), 173.

Deshwall, RPS, Singh, R, Malik, K, Randhawa, GJ (2005). Assessment of genetic diversity and genetic relationships among 29 populations of Azadirachta indica A. Juss. using RAPD markers. Genetic Resources and Crop Evolution, 52, 285-292.

Doyle, JJ, \& Doyle, JL (1990). Isolation of plant DNA from fresh tissue. Focus, 12, 13-15.

Forest Survey of India (2011). State of Forest report, Dehra Dun: FSI.

Gielis, J, Everaert, I, De Loose, M (1997). Analysis of genetic variation and relationships in Phyllostachys (Poaceae: Bambusoideae) using random amplified polymorphic DNA markers. In G Chapman (Ed.), The bamboos, (pp. 107-124). London: Academic Press.

Hamrick, JL, \& Godt, MJ (1990). Allozyme diversity in plant species. In: A. H. D. Brown, M. T. Clegg, A. L. Kahler, \& B. S. Weir (Eds.), Plant population genetics, breeding, and genetic resources, (pp. 43-63), Sunderland: Sinauer.

Hufford, KM \& Mazer, SJ (2003). Plant ecotypes: genetic differentiation in the age of ecological restoration. Trends in Ecology and Evolution, 18(3), 147-155. 
John, CK, Nadgauda, RS, Mascarenhas, AF (1994). Some interesting observations on the flowering and seeding in Melocanna bambusoides. Journal of Cytology and Genetics, 29, 161-165.

John, CK, Nadgauda, RS, Mascarenhas, AF (1995). Floral biology and breeding behaviour in Bambusa arundinacea. Journal of Cytology and Genetics, 30, 101-107.

Kawecki, TJ, \& Ebert, D (2004). Conceptual issues in local adaptation. Ecology Letters, 7(12), 1225-1241.

Lewontin, RC (1972). Testing the theory of natural selection. Nature, 236, 181-182.

Müller-Stark, G (1997). Biodervisitat und Nachhaltige Forstwirtschaft. Landsberg, Germany: Ecomed.

Muthukumar, T, \& Udaiyan, K (2006). Growth of nursery-grown bamboo inoculated with abruscular mycorrhizal fungi and plant growth promoting rhizobacteria in two tropical soil types with and without fertilizer application. New Forests, 31, 469-485.

Nadgauda, RS, John, CK, Mascarenhas, AF (1993). Floral biology and breeding behaviour in a bamboo-Dendrocalamus strictus Nees. Tree Physiology, 13, 401-408.

Nayak, S, Rout, GR, Das, P (2003). Evaluation of genetic variability in bamboo using RAPD markers. Plant Soil and Environment, 49, 24-28.

Nei, M (1973). Analysis of gene diversity in subdivided populations. Proceedings of the National Academy of Sciences, USA, 70, 3321-3323.

Nei, M, \& Li, WH (1979). Mathematical model for studying genetic variation in terms of restriction endonucleases. Proceedings of the National Academy of Sciences, USA, 76, 5269-5273.

Oleksyn, J, Modrzynski, J, Tjoelker, MG, Zytkowiak, R, Reich, PB, Karolewski, P (1998). Growth and physiology of Picea abies populations from elevational transects: common garden evidence for altitudinal ecotypes and cold adaptation. Functional Ecology, 12(4), 573-590.

Palmroth, S, Berninger, F, Nikinmaa, E, Lloyd, J, Pulkkinen, P, Hari, P (1999). Structural adaptation rather than water conservation was observed in Scots pine over a range of wet to dry climates. Oecologia, 121(3), 302-309.

Peuke, AD, Schraml, C, Hartung, W, Rennenberg, H (2002). Identification of drought-sensitive beech ecotypes by physiological parameters. New Phytologist, 154(2), 373-387.

Prevost, A, \& Wilkinson, MJ (1999). A new system of comparing PCR primers applied to ISSR fingerprinting of potato cultivars. Theoretical and Applied Genetics, 98, 107-112.

Rawat, S (2005). Bamboo-endomycorrhiza: ecology, growth and macroproliferation. Ph. D. thesis, 200p, Forest Research Institute (Deemed) University, Dehradun.

Rohlf, FJ (1998). NTSYS: numerical taxonomy and multivariate analysis system, $2^{\text {nd }}$ ed. Exeter Software, Stony Brook State University of New York.

Roldan-Ruiz, I, Dendauw, J, Van Bockstaele, E, Depicker A, \& De Loose, M (2000). AFLP markers reveal high polymorphic rates in ryegrasses (Lolium spp.). Molecular Breeding, 6, 125-134.

Savolainen, O, Pyhäjärvi, T, Knürr, T (2007). Gene flow and local adaptation in forest trees. Annual Review of Ecology, Evolution, and Systematics, 37, 595-619.

Soolanayakanahally, RY, Guy, RD, Silim, SN, Drewes, EC, Schroeder, WR (2009). Enhanced assimilation rate and water use efficiency with latitude through increased photosynthetic capacity and internal conductance in balsam poplar (Populus balsamifera L.) Plant, Cell and Environment, 32(12), 1821-1832.

Tewari, DN (1992). Bamboo. Dehradun: International Book Distributors.

Varmah, JC, \& Bahadur, KN (1980). Country report: India in Bamboo research. In: Lessard G, \& Choulnard, A. (Eds.), Asia Proceedings of a workshop, IDRC, Ottawa, IUFRO, (pp. 19-46), 28-30 May, Singapore.

Venkatesh, CS (1984). Dichogamy and breeding system in a tropical bamboo, Ochlandra travancorica. Biotropica, 16, 309-321.

Yang, H-Q, An, M-Y, Gu, Z-J, Tian, B (2012). Genetic diversity and differentiation of Dendrocalamus membranaceus (Poaceae: Bambusoideae), a declining bamboo species in Yunnan, China as based on inter-simple sequence repeat (ISSR) analysis. International Journal of Molecular Sciences, 13, 4446-4457.

Yeh, FC, Yang, RC, \& Boyle, T (1999). POPGENE version 1.31: Microsoft Windows - based freeware for population genetic analysis, quick user guide. Edmonton Centre for International Forestry Research, University of Alberta. Website: http://ualberta.ca/ fyeh/popgene.html. http://www.thehindu.com/ news/national/green-india-mission-to-double-afforestation-efforts-by-2020/ article438506.ece).

\section{Submit your manuscript to a SpringerOpen ${ }^{\circ}$ journal and benefit from:}

- Convenient online submission

- Rigorous peer review

- Open access: articles freely available online

- High visibility within the field

- Retaining the copyright to your article

Submit your next manuscript at springeropen.com 